\title{
Individuals with HIV/AIDS: Clinical Manifestations in the Oral Cavity in the Post-HAART Era
}

\author{
Ranjitha Krishna, Saiprasad Zemse and Scott Derossi \\ Georgia Health Sciences University, College of Dental Medicine \\ United States of America
}

\section{Introduction}

Oral lesions are very common in individuals with HIV (human immunodeficiency virus) infection and AIDS (acquired immune deficiency syndrome). They are reported to occur in $50 \%$ of people infected with HIV and in about $80 \%$ of people diagnosed with AIDS (Palmer, et al., 1996). Introduction of HAART (highly active anti-retroviral therapy) in 1996 has reduced the mortality and morbidity in people affected with HIV and AIDS as well as improved their quality of life. It has also resulted in a decrease, to a certain extent, in the incidence and prevalence of oral lesions.

Since HIV infection was first diagnosed in 1981, a variety of oral lesions has been associated with infected individuals, and they can be good indicators of the disease in otherwise healthy people. Oral lesions can also help determine the progression of the disease. In developed countries, CD4 lymphocyte counts and HIV viral load are the two main laboratory markers that are used to determine disease progression. However, in certain developing countries, people do not always have access to these tests, and severity of the oral lesions can serve as good indicators of disease progression.

Table 1 highlights the importance of diagnosing and treating oral lesions in individuals with HIV (Coogan, et al., 2005)

1. Can help diagnose the presence of HIV infection in otherwise healthy individuals

2. Develop early in an infection

3. Help determine the progression of HIV infection to AIDS

4. Entry and end-points in vaccine trials

5. Used in staging and classification of HIV diseases as determinants of opportunistic infection and anti-HIV therapy

Table 1. Importance of oral manifestations of HIV disease

\subsection{Classification of oral lesions associated with HIV}

The EC-Clearinghouse on oral problems related to HIV infection and WHO Collaborating Centre on Oral manifestations of the immunodeficiency virus proposed the classification of oral manifestations of HIV infection in September of 1992 based on their strength of 
association with the presence of HIV infection: ("Classification and Diagnostic Criteria for Oral Lesions in HIV Infection. EC-Clearinghouse on Oral Problems Related to HIV Infection and WHO Collaborating Centre on Oral Manifestations of the Immunodeficiency Virus," 1993). More recently in 2002, an international workshop was convened to discuss the classification of oral lesions associated with HIV/AIDS almost 2 decades after the virus was first identified (Patton, et al., 2002) and it was agreed that the original EC-Clearinghouse classification could still be used in current times. Table 2 summarizes the classification of oral lesions associated with HIV.

\begin{tabular}{|c|c|c|}
\hline $\begin{array}{l}\text { Group 1: Lesions strongly } \\
\text { associated with HIV } \\
\text { infection }\end{array}$ & $\begin{array}{l}\text { Group 2: Lesions less } \\
\text { commonly associated with } \\
\text { HIV infection }\end{array}$ & $\begin{array}{l}\text { Group 3: Lesions seen in } \\
\text { HIV infection }\end{array}$ \\
\hline $\begin{array}{l}\text { Candidiasis } \\
\text { Hairy leukoplakia } \\
\text { Kaposi's sarcoma } \\
\text { Non-Hodgkin's lymphoma } \\
\text { Periodontal disease (linear } \\
\text { gingival erythema, } \\
\text { necrotizing ulcerative } \\
\text { gingivitis, necrotizing } \\
\text { ulcerative periodontitis) }\end{array}$ & $\begin{array}{l}\text { Bacterial infections: } \\
\text { Mycobacterium avium- } \\
\text { intracellularae } \\
\text { Mycobacterium tuberculosis } \\
\text { Melanogic } \\
\text { hyperpigmentation } \\
\text { Necrotizing (ulcerative) } \\
\text { stomatitis } \\
\text { Salivary gland disease } \\
\text { Dry mouth due to } \\
\text { decreased salivary flow } \\
\text { Unilateral/bilateral } \\
\text { swelling of salivary glands } \\
\text { Thrombocytopenia purpura } \\
\text { Non-specific ulcerations } \\
\text { Viral infections: } \\
\text { Herpes simplex virus } \\
\text { Human papillomavirus } \\
\text { Condyloma acuminatum } \\
\text { Focal epithelial hyperplasia } \\
\text { Verruca vulgaris } \\
\text { Varicella-zoster virus }\end{array}$ & $\begin{array}{l}\text { Bacterial infections: } \\
\text { Actinomyces israelii } \\
\text { Escherichia coli } \\
\text { Klebsiella pneumonia } \\
\text { Cat-scratch disease } \\
\text { Drug reactions (ulcerative, } \\
\text { erythema multiforme, } \\
\text { lichenoid, toxic } \\
\text { epidermolysis) } \\
\text { Epitheliod (bacillary) } \\
\text { angiomatosis } \\
\text { Fungal infection other than } \\
\text { candidiasis } \\
\text { Cryptococcus neoformans } \\
\text { Geotrichum candidum } \\
\text { Histoplasma capsulatum } \\
\text { Mucoraceae (mucomycosis } \\
\text { zygomycosis) } \\
\text { Aspergilus flavus } \\
\text { Neurological disturbances: } \\
\text { Facial palsy } \\
\text { Trigeminal neuralgia }\end{array}$ \\
\hline
\end{tabular}

Table 2. Classification of oral lesions associated with HIV

In this chapter, we will discuss only those lesions that are commonly seen in persons infected with HIV.

\section{Candidiasis}

\subsection{Background}

Candidiasis is a common opportunistic infection caused by an overgrowth of the Candida microorganisms already present in the oral cavity. Incidence of oral candidiasis has been 
high in developing countries (Tukutuku, et al., 1990). Since the discovery of HIV in 1981, candidiasis has been shown to be associated with HIV-infected individuals (Gottlieb, et al., 1981). Previous reports show that oral candidiasis occurs in $54-93 \%$ of individuals with AIDS (Schmidt-Westhausen, et al., 1991). In recent reports, due to the introduction of antiretroviral therapy only $20 \%$ of individuals infected with HIV showed oral candidiasis (Davies, et al., 2006).

\subsection{Pathogenesis}

Oral candidiasis is primarily caused by a dimorphic ubiquitous Candida albicans. The cell wall of Candida is primarily made up of three polysaccharides, mannan, glucan and chitin. Candida attaches to oral tissues and dentures with the help of adhesins such as Als1p, Als5p, Int1p and Hwp1p (Chaffin, et al., 1998, Hostetter, 1994). These glycoproteins bind to the extracellular matrix of mammalian cells such as fibrinogen, laminin and collagen (Chaffin, et al., 1998). Candidal adhesion to endothelial surfaces is achieved by the cell surface polysaccharide mannan, which binds to complement receptor 3 (CR3), an integrin found on human cells (Calderone and Braun, 1991). There is increased association of integrin analogs (iC3B and CR3d receptor) and fibronectin receptor with most of the virulent forms of Candida (Ollert, et al., 1990). Thus, CR3-like proteins promote adherence of Candida albicans to host cells.

\subsection{Clinical features}

There are three clinical forms of candidiasis: pseudo-membranous (thrush), erythematous (atrophic) and perioral angular chelitis. Proliferation of pseudomembranous fungi forms a gray-white structure composed of inflammatory substrate and matted organisms resting on an erythematous base. These lesions are most commonly evident on the tongue, buccal mucosa, hard and soft palate and pharyngeal tissues. The erythematous form shows mucosal hyperemia and inflammation with a reddened erythematous patches (Calderone and Fonzi, 2001). The mucous membrane appears dry, red and glazed. Affected individuals show burning sensitivity and pain sensation of dry mouth, odynophagia, dysgeusia and smell of yeast infection. Angular chelitis shows commissural involvement as erythematous/hyperkeratotic with fissuring and sensitivity. Individuals receiving HAART show low occurrence of these clinical features. Before the emergence of HAART, the incidence of oral candidiasis was relatively high in persons with AIDS.

\subsection{Treatment}

An early study for treatment of Candida infections was carried out by Williams in 1977, where nystatin was compared to no treatment in 56 patients (Williams, et al., 1977). Since then ketoconazole, fluconazole, clotrimazole, itraconazole, neomycin sulphate, colistin, trimethoprin and sulphamethoxazole have been tried in combination and at different concentrations for treatment of oral candidiasis (Hann, et al., 1982, Owens, et al., 1984, Palmblad, et al., 1992, Philpott-Howard, et al., 1993, Rozenberg-Arska, et al., 1991, Vogler, et al., 1987). Most recently ketoconazole and clotrimazole were found most effective in treatment of oral candidiasis (Worthington, et al., 2002). Initial local treatments are first line of therapy (Bensadoun, et al., 2008). Mucosal contact for 2 minutes is recommended either by rinsing, gargling or swallowing. 
Systemic treatments are considered in high-risk patients only when local therapy fails (Charlier, et al., 2006). When topical and systemic therapy fails, intravenously administered amphotericin $\mathrm{B}$ and echinocandins are considered in high-risk patients. Intermittent use of antifungal agents has been advocated to prevent development of resistant fungal infections (Samaranayake, et al., 2002). Recently, gel formulation of fluconazole has proven to be a better alternative treatment form than tablet formulation (Nairy, et al.).
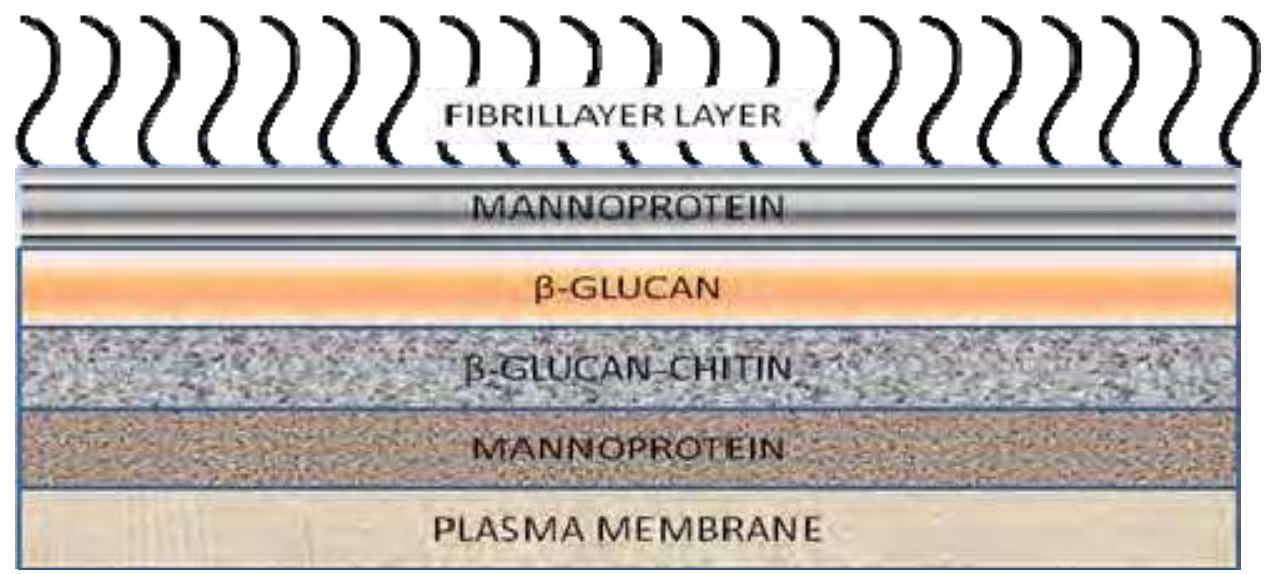

Fig. 1. Cell wall of Candida albicans

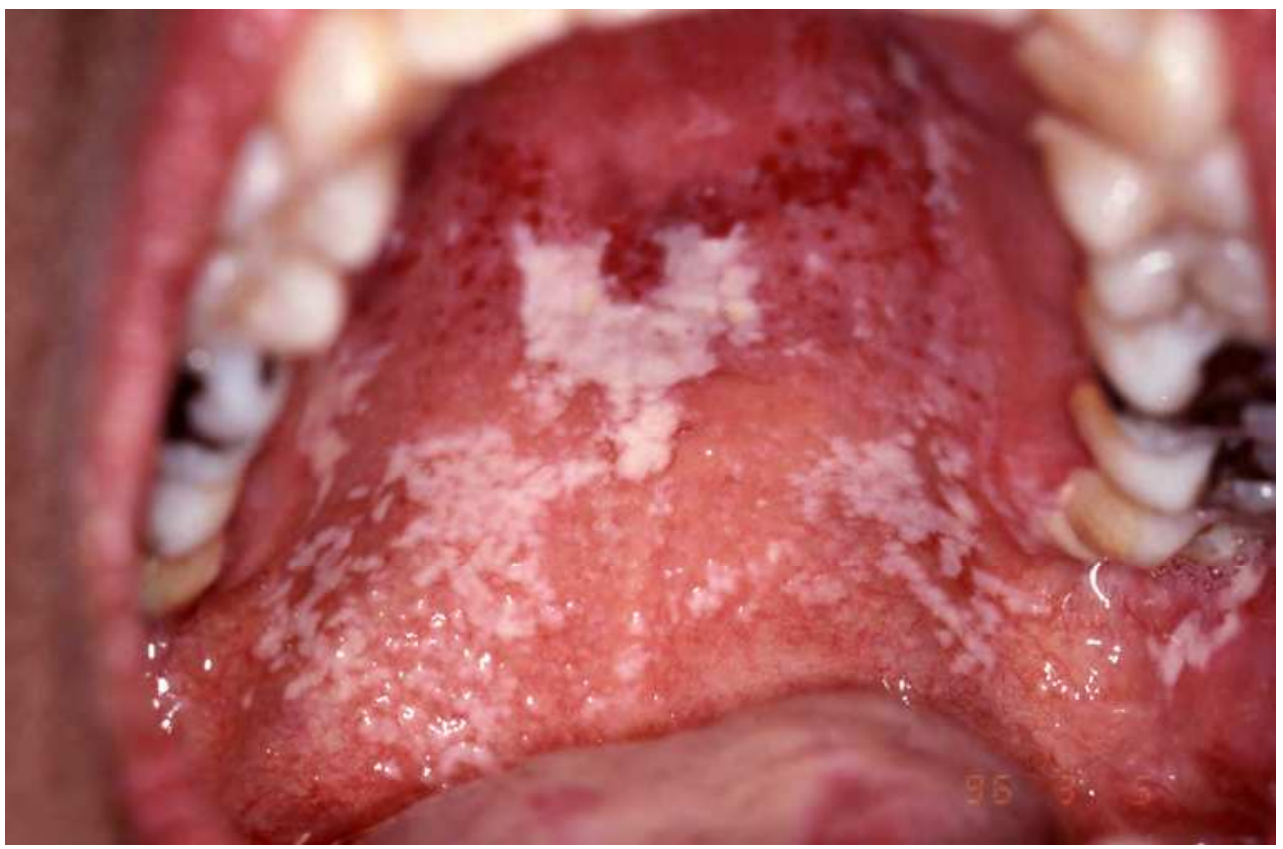

Fig. 2. Hypertrophic Candidiasis 


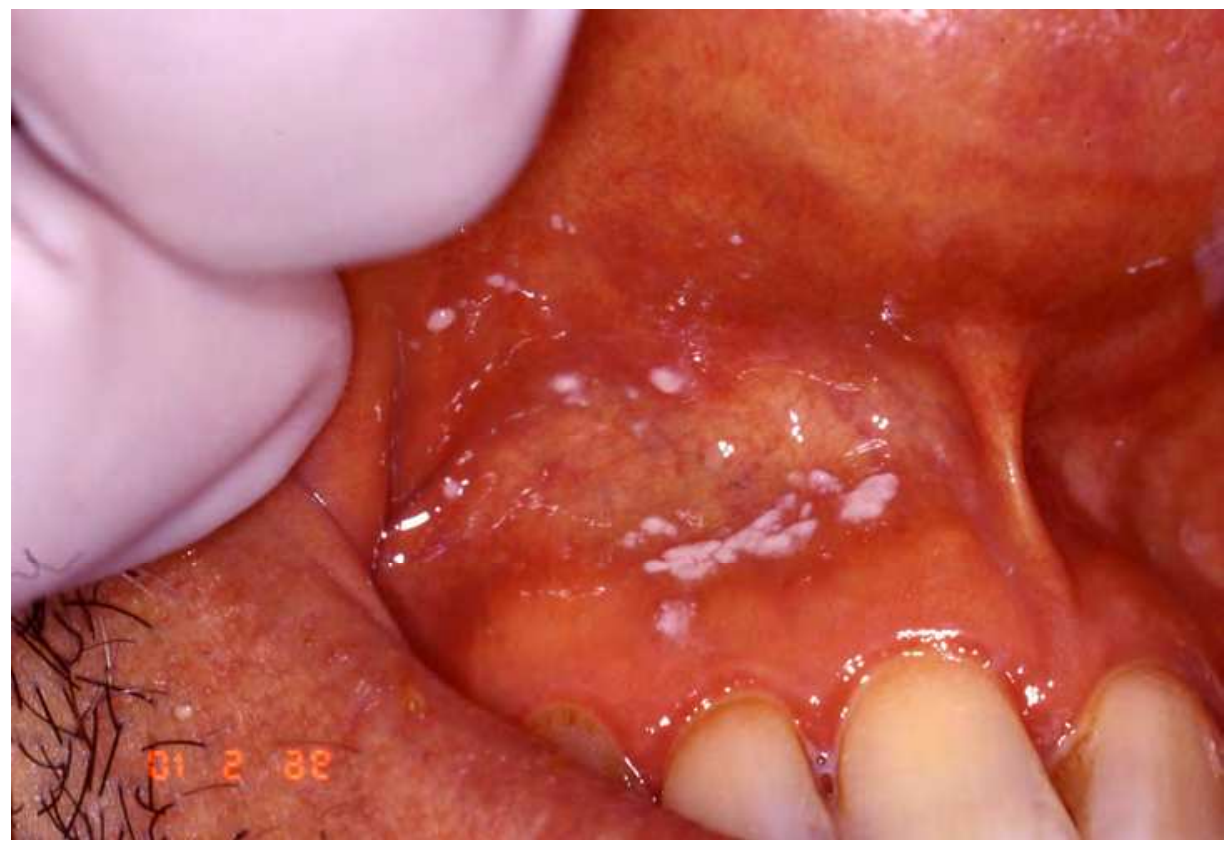

Fig. 3. Pseudo-membranous Candidiasis

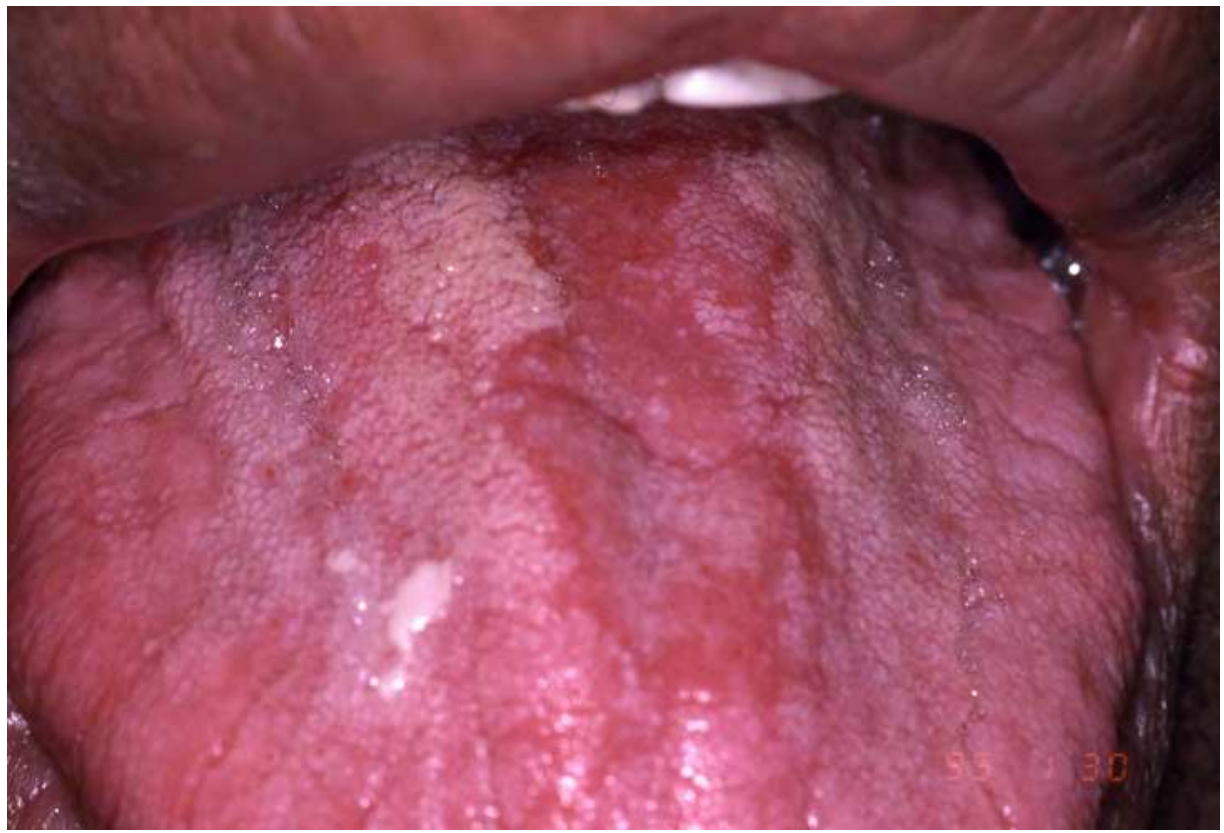

Fig. 4. Atrophic/Erythematous Candidiasis 


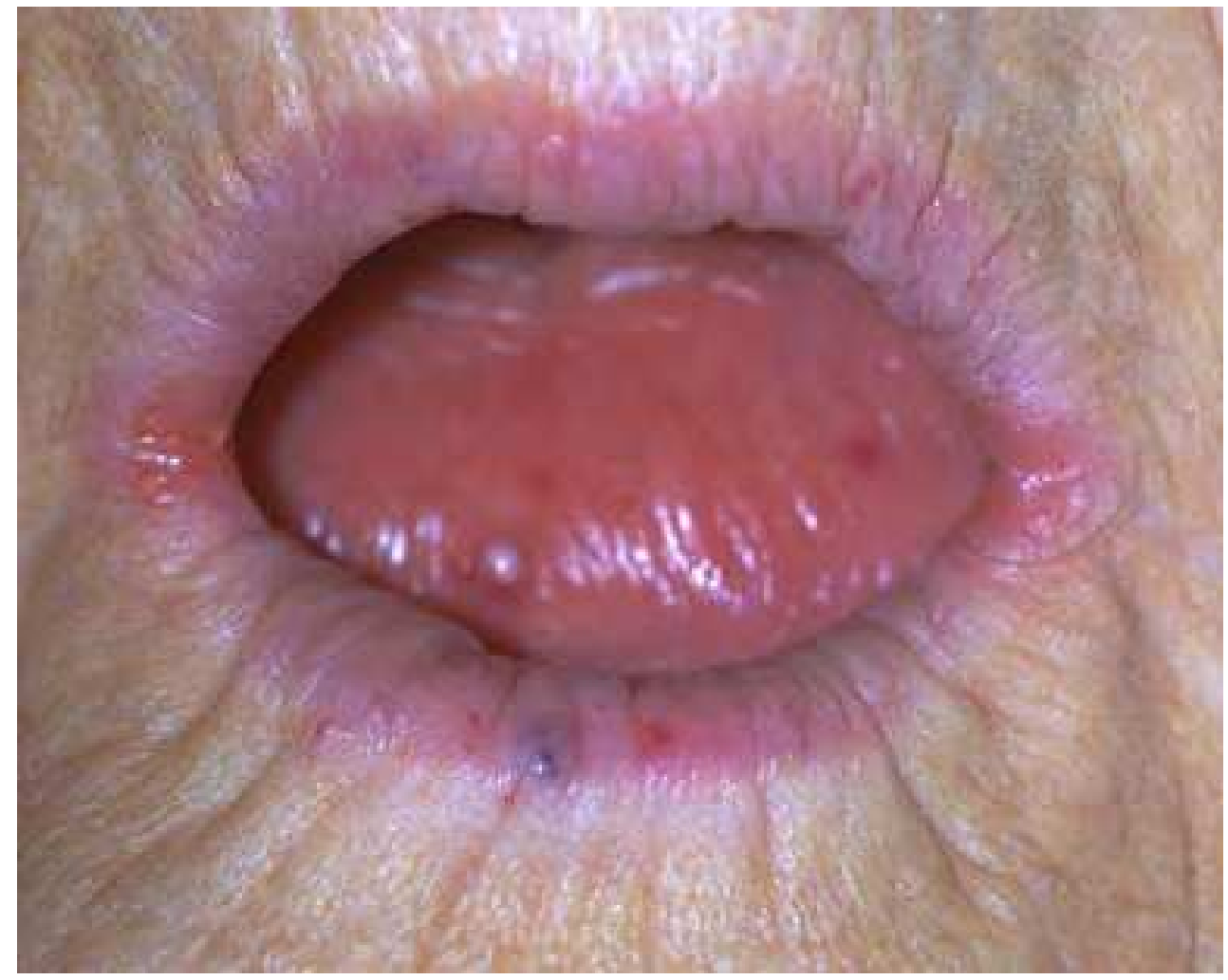

Fig. 5. Angular Chelitis

\section{Hairy leukoplakia}

\subsection{Background}

OHL (Oral hairy leukoplakia) is caused by Epstein-Barr virus and was first described in 1984. 50\% of individuals with HIV present with this condition and it is a very good indicator of immunosuppression. The lesion usually presents itself when the CD4 cell counts fall below $0.3^{*} 10^{9} / \mathrm{L}$ (Bravo, et al., 2006). According to the CDC (Centers for Disease Control and Prevention), this condition has a clear prognostic value in predicting the future development of AIDS ("1993 Revised Classification System for HIV Infection and Expanded Surveillance Case Definition for AIDS among Adolescents and Adults," 1992).

\subsection{Pathogenesis}

The pathogenesis of OHL is due to the replication of Epstein-Barr virus and increased virulence in conjunction with a decrease in local and systemic host immunity.

\subsection{Clinical features}

OHL present themselves as white, corrugated lesions on the lateral surface of the tongue and are not painful. There has been a decrease in the incidence of OHL due to the potent 
anti-retroviral drugs. However, if OHL is seen in an HIV-infected person, it may indicate failure of current therapy. Differential diagnosis of this condition includes oral candidiasis, lichen planus, other forms of leukoplakia, HPV (human papilloma virus) associated intraepithelial neoplasia, and oral squamous cell carcinoma.

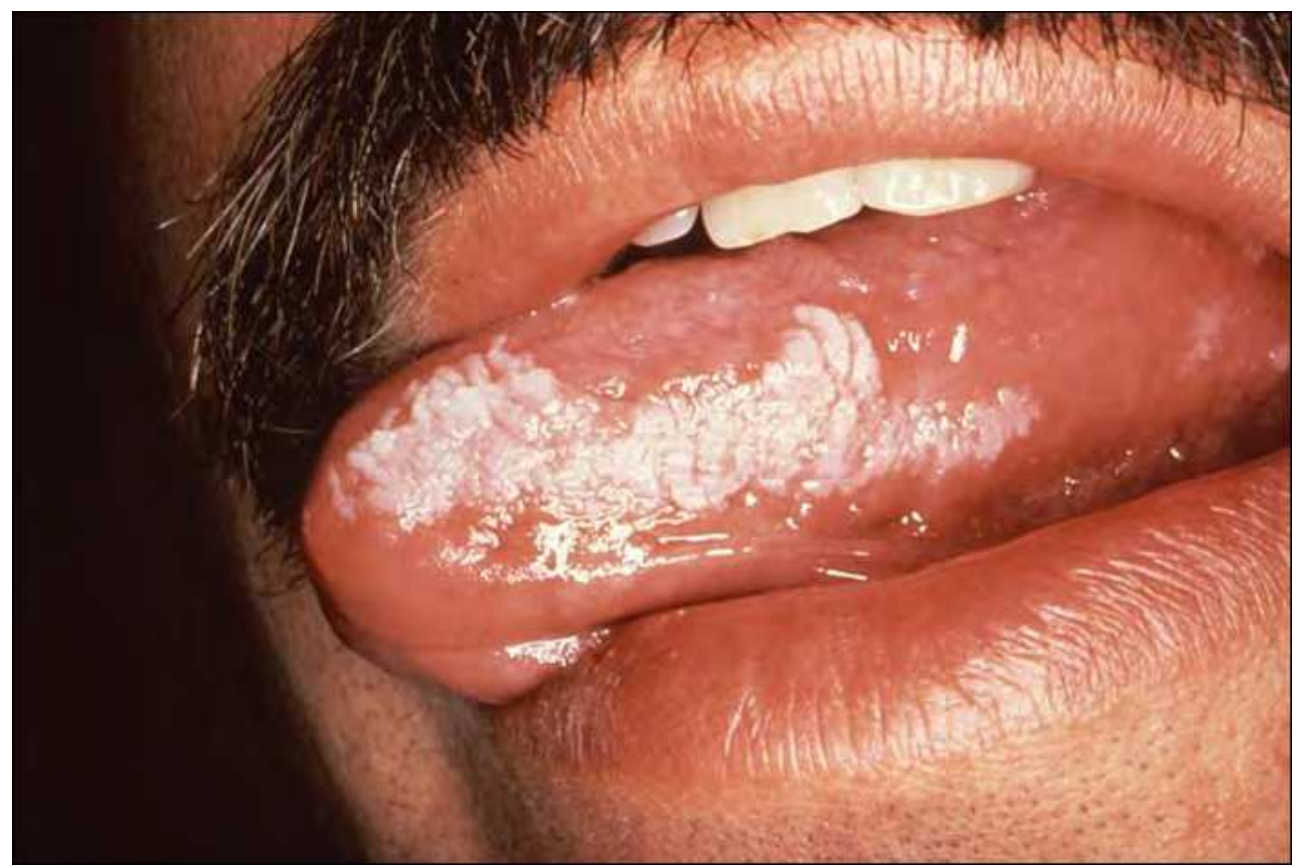

Fig. 6. Oral Hairy Leukoplakia

\subsection{Treatment}

$\mathrm{OHL}$ is a relatively benign condition with low morbidity and does not require any specific treatment. Most of the time, these lesions resolve spontaneously. However, several treatment options are available for those who feel uncomfortable or have cosmetic concerns due to the lesion. Since the lesion is caused by multiplication of the Epstein-Barr virus topical and systemic anti-viral agents work effectively in resolving the lesion. High doses of Acyclovir (800 mg 5 times a day) (Resnick, et al., 1988), Valacyclovir (1000 mg 3 times a day), and Famciclovir (500 mg 3 times a day) have all been shown to resolve the lesions in 1-2 weeks (Schofer, et al., 1987). However, once the effect of the anti-viral agent wears off, the lesions can recur several weeks later.

Topical application of Podophyllin resin in 25\% solution has produced resolution of the lesion in 1-2 weeks (Gowdey, et al., 1995). Topical therapy with retinoic acid has also been shown to cause resolve the lesions due to inhibition of Epstein-Barr virus replication. Ablative and cryotherapy have also had success in treatment of the lesions. Although the above treatment options are effective in resolving the lesion, OHL can recur several weeks after treatment since none of these agents eliminate the latent state of infection. 


\section{Kaposi's sarcoma}

\subsection{Background}

KS (Kaposi's sarcoma) is an angioproliferative tumor described by the Hungarian pathologist Moritz Kaposi in 1872. It is caused by KSHV (Kaposi's sarcoma-associated herpes virus) or $\mathrm{\gamma}$-herpes virus. KSHV belongs to the genus Rhadinovirus and has a DNA sequence similar to other rhadinoviruses (Albrecht, et al., 1992). With the introduction of HAART in 1996, the incidence of AIDS-related cancers such as KS and NHL (non Hodgkin's lymphoma) has decreased (Shiels, et al., 2008). During the 1980s and early 1990s, US population rates of KS increased 30 fold (Eltom, et al., 2002). There were no KS cases during 1975-1979, before the advent of AIDS. In an HIV cancer match study, 81\% of KS cases matched to HIV registries during 1980-2007 (Shiels, et al., 2011). AIDS occurred in a higher proportion of patients with Kaposi's sarcoma in age groups of 0-29 and 30-59 years (Shiels, et al., 2011).

\subsection{Pathogenesis}

KS lesions show varying cell diversity. Lesions are flat, comprising of inflammatory cells ( $\mathrm{T}$, B cells and monocytes). Neovascularization develops prior to development of these lesions and contain spindle-shaped cells. This dermal stage progresses to the plaque stage, in which the lesions are more indurated, edematous, and red or violet in color. The lesion eventually reaches the nodular stage and is characterized by visible masses with dominant spindle cells and inflammatory cells. These spindle cells express lymphatic-specific markers (e.g., Podoplanin and lymphatic vessel hyaluronan receptor LYVE-1) as well as participate in the signaling process during lymphangiogenesis (Skobe, et al., 1999, Weninger, et al., 1999).

\subsection{Clinical features}

There are four types of KS: classic type, endemic African KS, KS in organ transplant recipients, and HIV-infection/AIDS associated KS (Trattner, et al., 1993). KS is the most common neoplasm $(20-50 \%)$ found in HIV-infected individuals (mostly homosexual and bisexual men) (Scully, et al., 1991).Oral lesions are evident in 40\% of KS (Greenspan and Greenspan, 1990).Red or purplish macules, papules or nodules appear most frequently on the hard palate (Greenspan and Greenspan, 1990). Unless infected or ulcerated, these lesions do not blanch on pressure (Greenspan and Greenspan, 1990). Laryngeal involvement is also evident in individuals with KS (Pantanowitz and Dezube, 2006). Primary symptoms are hoarseness, throat discomfort, urge to cough, aphonia, dysphagia, stridor, and complete airway obstruction.

\subsection{Treatment}

The extent and bulk of the disease determines the therapeutic alternative that needs to be considered. Individuals with fewer than five cutaneous lesions are kept on watch until rapid proliferation, widespread dissemination or KS-related symptoms become more apparent. Treatment with HAART or other anti-retroviral therapies are beneficial and have shown histologic regression of existing lesions (Eng and Cockerell, 2004). HAART therapy causes inhibition of HIV replication, diminishes the HIV-1 transactivating protein Tat, ameliorates the immune response against KSHV, and shows direct anti-angiogenic activity (Cattelan, et al., 1999, Pati, et al., 2002, Sgadari, et al., 2002). Radiotherapy is 
indicated for lesions on the face, hands and upper extremities, obstructive lymphadenopathy, periorbital edema, lesions on soles of the feet, anorectal or genital lesions, oral lesions and ulcerating cutaneous lesions. Radiotherapy shows merits in symptomatic disease where systemic treatment is not necessary and expensive chemotherapy can be avoided (Swift, 1996). If an active opportunistic infection is observed, chemotherapeutic agents should be considered. Systemic chemotherapeutic treatment is indicated in extensive KS of oral cavity, widespread skin involvement, pedal or scrotal edema, symptomatic visceral involvement and flare induced by immune reconstitution inflammatory syndrome (Osoba, et al., 2001). Individuals may suffer from neutropenia and thrombocytopenia and hence controlled therapy should be the choice of treatment. Only nodular and symptomatic lesions of oropharynx should be treated with radiation. Recombinant and non-recombinant alpha interferons can be used for treatment of epidemic KS (De Wit, et al., 1988).

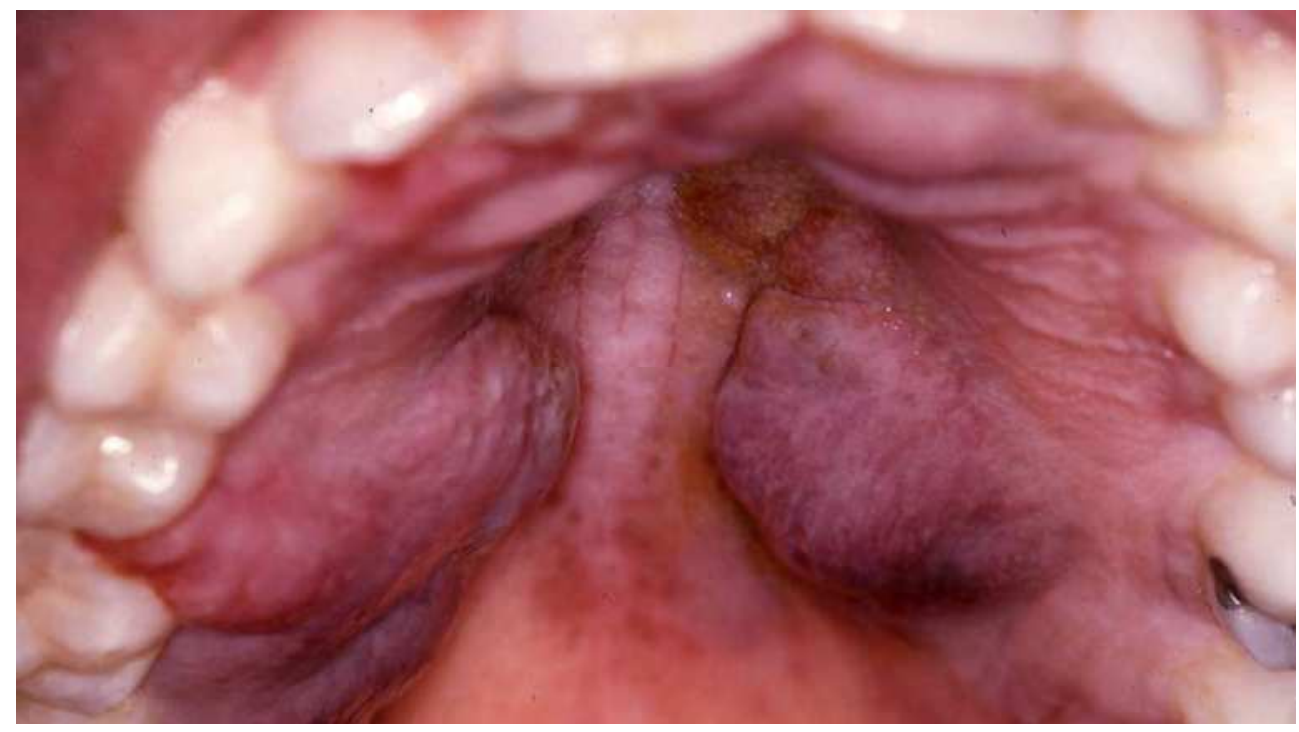

Fig. 7. Kaposi's Sarcoma

\section{Human Papilloma Virus (HPV) infections}

\subsection{Background}

HPV is the leading cause of orpharyngeal carcinomas (D'Souza, et al., Rosenquist, 2005). HPV16 is a common cause for the majority of oropharyngeal carcinomas (Kreimer, et al., 2005) . HPV-positive individuals are most frequently Caucasian and belong to high socioeconomic status (Gillison, et al., 2008). HIV-infected individuals have two to four-fold increase in risk for developing HPV-related oral cancers (Gilbert, et al.). HPV has also been considered as one of the etiologic factors for OHL (oral hairy leukoplakia) (Fejerskov, et al., 1977), as shown by identification of HPV antigens and HPV DNA (Loning, et al., 1985). HPV-induced OL shows prevalence ranged from $17 \%$ to $68.6 \%$ (Shroyer, et al., 1993, Sugiyama, et al., 2003). 


\subsection{Pathogenesis}

HPV is mainly infectious through expression of oncogenes such as E6/E7 (Al-Bakkal, et al., 1999), which cause phosphorylation of CHK2, leading to caspase activation (Al-Bakkal, et al., 1999, Moody and Laimins, 2009, Tominaga, et al., 1999). The intrinsic apoptotic pathway of caspase activation plays an important role in HPV replication (Moody, et al., 2007). HPV proteins flourish and regulate amplification primarily by caspase activation, leading to immortalization of the suprabasal layer of epithelium, specifically the keratinocytes (Sakai, et al., 1996).

\subsection{Clinical features}

HPV induced oral and pharyngeal cancers are most evident in younger females ( $<40$ years). OSCC (oral squamous cell carcinoma) normally occur on the buccal mucosa (2-10\%), lip (4$40 \%)$, alveolar ridge (2-18\%) retromolar trigonous (2-6\%), hard palate (3-6\%), floor of mouth $(25 \%)$, ventral two third of tongue (50\%), alveolar ridge $(2-18 \%)$, floor of mouth $(25 \%)$ and oropharynx (25\%). Squamous cell carcinoma of the oropharynx most commonly originates in the tonsils and tongue base (the two most common sites), pharyngeal walls, and soft palate.

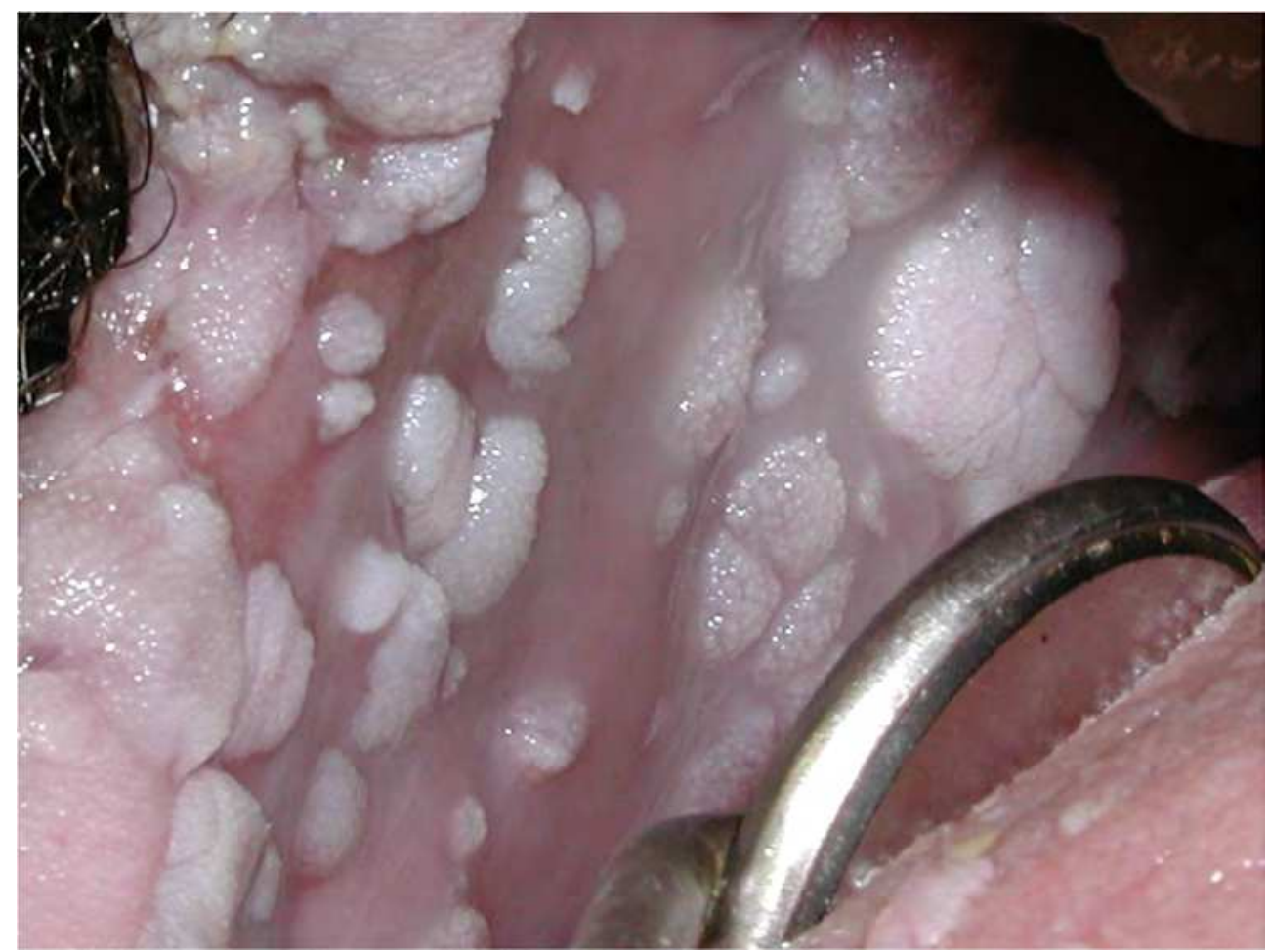

Fig. 8. Human Papilloma Virus Lesions 


\subsection{Treatment}

Treatment of HPV infection can be achieved either by use of targeted therapy against the virus or immune-stimulating therapy. Most dysplastic tissue can be treated by ablative and excisional therapy. Use of radiochemotherapy in the form of radiation \pm cisplatin or cetuximal has shown beneficial results in treatment of oropharyngeal carcinoma. The overall survival rate was $60 \%$ in HPV-positive individuals and $73 \%$ in HPV-negative individuals (Lill, et al.).

\section{Periodontal lesions associated with HIV}

\subsection{Linear Gingival Erythema (LGE) 6.1.1 Background}

This lesion is also known as 'red-band gingivitis' or 'HIV-associated gingivitis'. LGE is commonly seen in immune-compromised individuals and is considered to be a potential precursor for necrotizing ulcerative gingivitis (NUG)/ necrotizing ulcerative periodontitis (NUP). According to the recent classification of periodontal diseases (Armitage, 1999), LGE is classified under 'Gingival diseases of fungal origin.'

\subsubsection{Pathogenesis}

There is an increased number of bacteria and Candida species in the gingival sulcus associated with LGE. The bacteria seen include those commonly observed in periodontal disease such as Bacteriodes gingivalis, Bacteriodes intermedius, Actinomyces viscosus, Fusobacterium nucleatum, and Aggregatibacter actinomycetemcomitans.

\subsubsection{Clinical features}

The lesions present themselves as 2-3 mm wide red band around the marginal gingival of the teeth. These lesions are not typically painful, but bleed readily.

\subsubsection{Treatmen}

Typically, no treatment is needed for this condition. Although LGE is listed under 'Lesions of fungal origin', it is not typically treated with anti-fungal medications. Mechanical removal of plaque and calculus helps reduce inflammation and excessive bleeding. Chlorhexidine gluconate $(0.12 \%)$ mouth rinses can be used twice daily. If the lesion persists, systemic antibiotics (metronidazole) may be prescribed to reduce the bacterial load.

\subsection{Necrotizing Ulcerative Gingivitis and Periodontitis (NUG and NUP)}

\subsubsection{Background}

NUG is a painful condition of the gingiva characterized by ulcerations, bleeding, and foul breath. It is also called Vincent's infection, Vincent's angina, or trench mouth. When the infection spreads to the alveolar bone, it is called NUP. Prevalence of NUP in HIV-infected individuals has been reported by various researchers. Its prevalence with HIV was reported in 1994 as 6\% (Glick, et al., 1994). Over a period of a decade, the incidence of HIV in NUP patients increased to $69.6 \%$ (Shangase, et al., 2004). Recent reports suggest $43 \%$ of patients with NUP were HIV-seropositive (Phiri, et al.). Studies have shown that HIV-infected individuals with NUP are $20.8 \%$ more likely to have a CD4+ count lower than 200 (Glick, et al., 1994). 


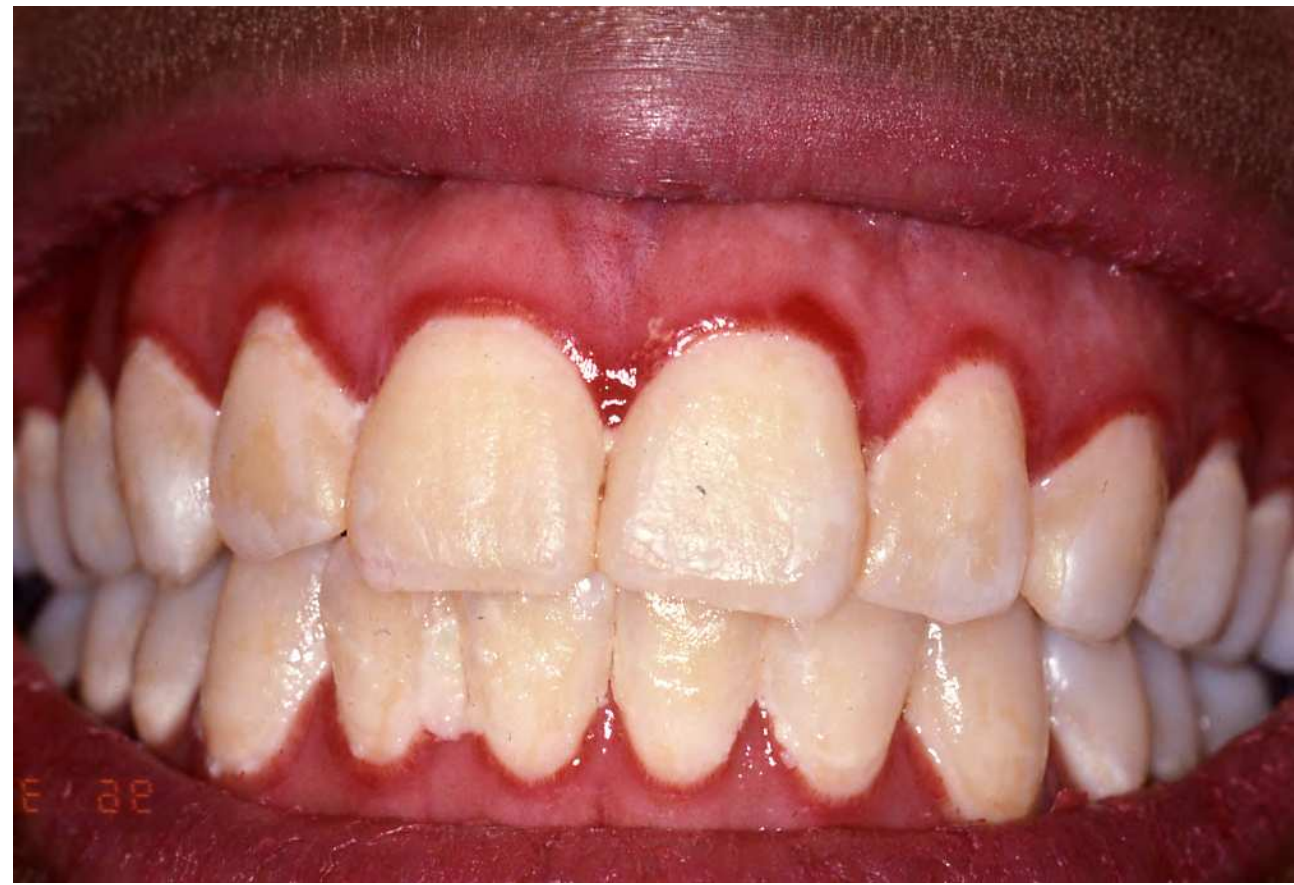

Fig. 9. Linear Gingival Erythema

\subsubsection{Pathogenesis}

NUP is commonly a progression of NUG that demonstrates bone loss and clinical attachment levels (MacCarthy and Claffey, 1991). Both are primarily caused by bacterial infection with microflora consisting of Treponema and Selenomonas species, Prevotella intermedia, Fusobacterium nucleatum and Porphyromonas gingivalis (Falkler, et al., 1987, Loesche, et al., 1982). Malnutrition, smoking, stress, trauma and preexisting gingivitis are other etiologic factors (Peruzzo, et al., 2007, Taiwo, 1993). Most persons with NUG have alterations in the immune system making them more prone to microbial infections (Cogen, et al., 1983). This immunosuppression is also evident in infection by HIV (Goedert, et al., 1984). Treponema denticola (T. denticola) is the principal oral helical-shaped anaerobic spirochete that plays an essential role in immunosuppression. The disease process is mediated through adherence to mucosal surfaces, specific cleavage of cell surface receptors, inhibition of host defense mechanisms, penetration in epithelial cells, and induction of gingival inflammation and bone resorption. Proteases such as chymotrypsin, phospholipase C, oligopeptidase and cystalysin play an important role in pathogenicity (Chi, et al., 2003, Ellen and Galimanas, 2005, Fenno and McBride, 1998) and is induced by a range of proinflammatory cytokines such as IL-1 $\alpha$, IL-1 $\beta$, tumor necrosis factor- $\alpha$, IL-6 and IL-8 (Gemmell and Seymour, 1998, Nixon, et al., 2000). These cytokines affect connective tissue destruction and alveolar bone desorption (Gemmell and Seymour, 1998). Phosphorylation of intracellular receptors such as Fos-c, MKK1, MAP kinase and nuclear factor KB molecules by T. denticola affect these changes (Tanabe, et al., 2008). 


\subsubsection{Clinical features}

The clinical characteristics of NUG includes ulcerated and necrotic papillary and marginal gingival covered by a yellowish-white or grayish slough or "pseudomembrane", blunting and cratering of papillae, spontaneous bleeding or bleeding on probing, pain and fetid breath (Barnes, et al., 1973, Falkler, et al., 1987, Horning and Cohen, 1995). It may be accompanied by fever, lymphadenopathy, and malaise. Progression of gingivitis to NUP is commonly associated with clinical attachment loss and alveolar bone destruction.

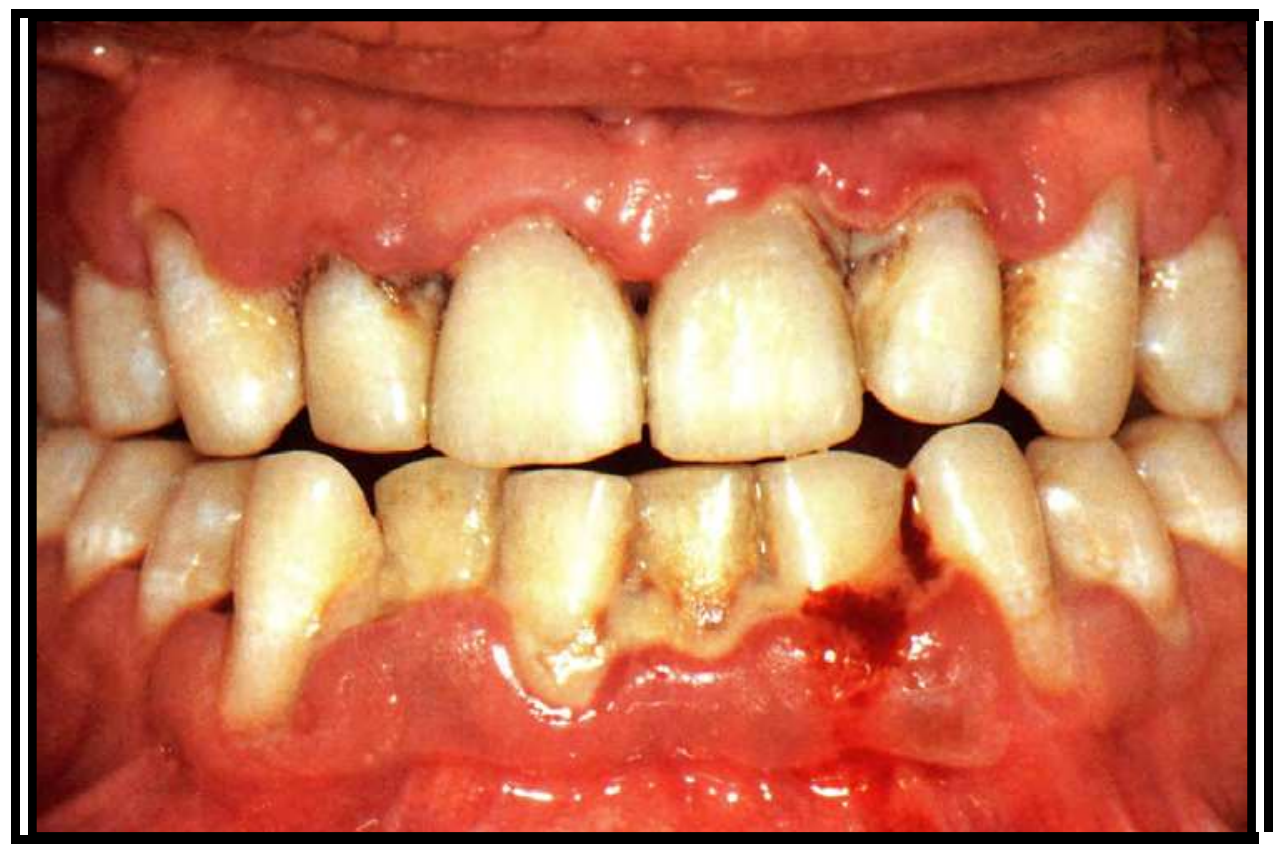

Fig. 10. Necrotizing Ulcerative Periodontitis

\subsubsection{Treatment}

The first treatment for NUG was devised by Dr. S. Schluger in 1949 (Schluger, 1949).Bacterial pathogens were controlled or eliminated by mechanical debridement or use of antibiotics in earlier days (Johnson and Engel, 1986). Aureomycin and penicillin were the first antibiotics considered for treatment of NUG in 1950 (Goldman and Bloom, 1950, Montis, 1950). Mechanical treatment consists of scaling and root planing. In addition to mechanical debridement, antibiotic and antimicrobial therapies are essential for management of NUP. Oxidizing mouthwash such as 3\% hydrogen peroxide has also shown to have beneficial effects in management of NUG and NUP.

\section{Non-Hodgkin lymphoma}

\subsection{Background}

There are three subtypes of on-Hodgkin's lymphoma (NHL): diffuse large B cell lymphoma (DLBCL), Burkitt's lymphoma (BL) and central nervous system lymphoma (CNSL)(Engels, 
et al., 2006). An increase in occurrence of DLBCL (10.2\%), BL (27.8\%) and CNSL (48.3\%) was seen in individuals with AIDS during 1990-1995 (Shiels, et al., 2011). The 5-year survival rate improved from 1960 to the mid 1970s, but not much after that in the USA (Shiels, et al., 2011). NHL relates to congenital and acquired immunodeficiency diseases (Filipovich, et al., 1992). The relative risk of NHL in individuals with AIDS is about 150-250 in Western countries and over 1000 in children (Goedert, 2000).

\subsection{Pathogenesis}

The head and neck regions are the most common sites for NHL, showing in 30-40\% of cases (Economopoulos, et al., 1996). The neoplastic cells express CD20, CD79, BCL-2 and BCL-6, most of which are B-cell antigens (Hoefnagel, et al., 2003). The hallmark of B-cell malignancies is chromosomal translocation involving the immunoglobulin heavy chain (IGH) gene at band 14q32.33 with specific oncogene loci, referred to as the $14 q 32$ translocation. Among these specific 14q32 translocations, de novo acute leukemia/lymphoma with c-MYC and/or BCL6 abnormalities in addition to $t(14 ; 18)$ was characterized by an extremely aggressive clinical course with nodal and/or extranodal involvement, and massive bone marrow infiltration(Kramer, et al., 1991). Incidence of IGH translocation on Bcell NHL has been reported in previous studies (Kramer, et al., 1998). Thus multiple involvement of the IGH gene in chromosomal rearrangements is associated with the pathogenesis and the progression of NHL.

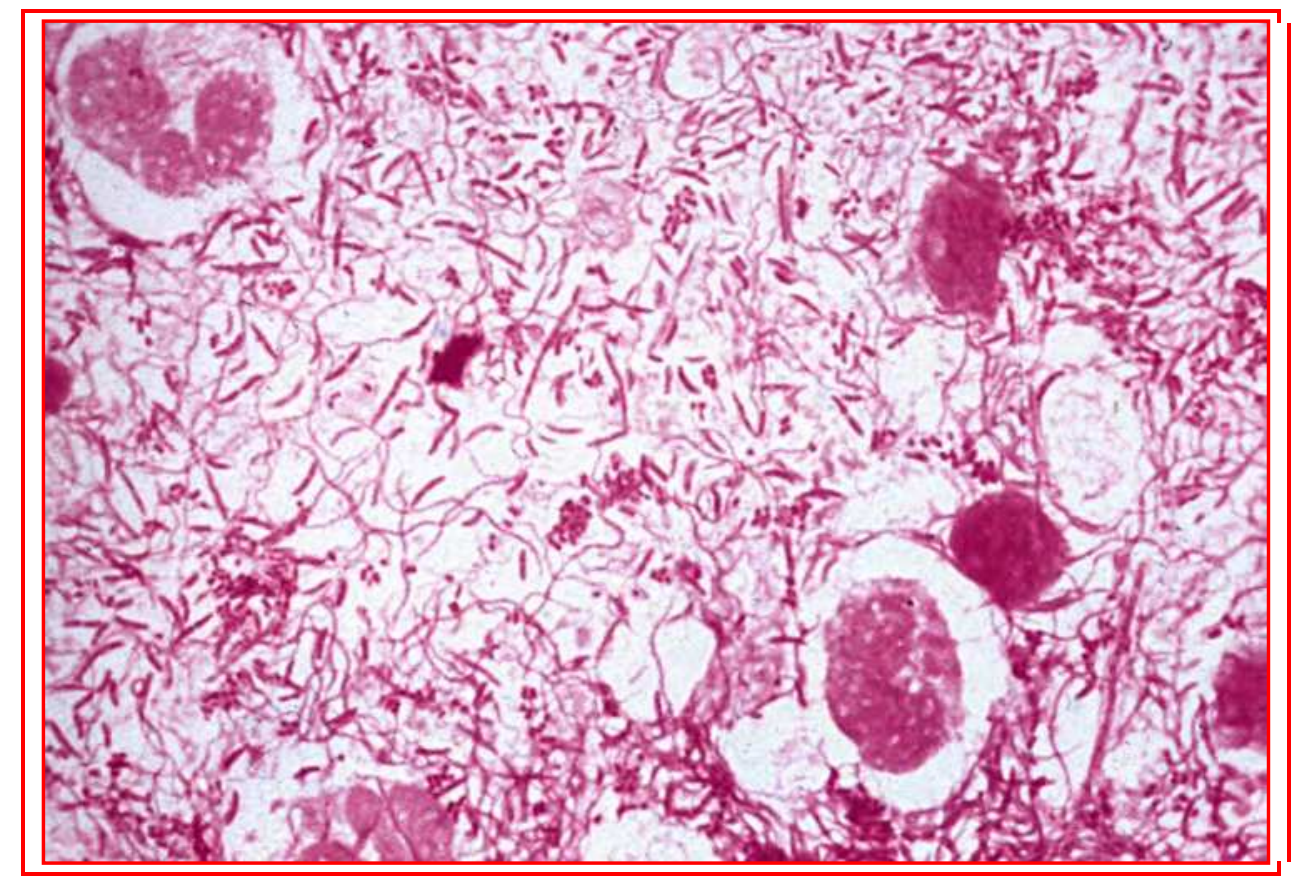

Fig. 11. Histology of NUP lesion- Infiltration of Spirochetes into the Connective Tissue 


\begin{tabular}{|l|l|}
\hline Stage I & $\begin{array}{l}\text { Involvement of a single lymph node region (I) or a single } \\
\text { extralymphatic organ or site (IE) }\end{array}$ \\
\hline Stage II & $\begin{array}{l}\text { Involvement of two or more lymph node regions on the same side } \\
\text { of the diaphragm (II) alone or with localized involvement of an } \\
\text { extralymphatic organ or site (IIE) }\end{array}$ \\
\hline Stage III & $\begin{array}{l}\text { Involvement of lymph node regions on both sides of the } \\
\text { diaphragm (III) alone or with localized involvement of an } \\
\text { extralymphatic organ or site (IIIE) or spleen (IIIS) or both (IIISE) }\end{array}$ \\
\hline Stage IV & $\begin{array}{l}\text { Diffuse or disseminated involvement of one or more } \\
\text { extralymphatic organs with or without associated lymph node } \\
\text { involvement }\end{array}$ \\
\hline
\end{tabular}

Table 3. Ann Arbor Classification of Non-Hodgkin's Lymphomas (Rupniewska, 1979)

\subsection{Clinical features}

Oral NHL lesions are often in disseminated disease states. The most common oral sites of involvement are the palate, tonsil, buccal mucosa, floor of the mouth, and the retromolar region. These lesions are non-tender, diffuse swellings usually involving the gingiva, buccal vestibule and posterior hard palate. Gnathic lesions arise from soft tissue invading the bony skeleton. One third of patients show fever, weight loss, adenopathy, night sweats, or hepatosplenomegaly. Oral lesions are fluctuant swellings showing ulceration, pain, tooth mobility and paresthesia when peripheral nerves are involved (Vega, et al., 2005). Salivary gland lymphomas account for approximately 3\% of all salivary gland tumors (Barnes, et al., 1998). About $80 \%$ of the cases are reported in parotid gland, $16 \%$ in submandibular, $2 \%$ in sublingual and $2 \%$ in minor salivary glands. Affected bony areas show a "punched out" pattern that is due to multiple areas of destruction with ill defined radiolucent lesion. Involvement of the maxillary sinus will cause opacification with eroded cortical walls and associated sinus mass (Fukuda, et al., 1987). The Ann Arbor staging system, originally designed for Hodgkin's disease, is used for NHL as evident above.

\subsection{Treatment}

A prognostic index has been developed by the International NHL prognostic factors project based on data from 2,031 patients with aggressive lymphomas treated with regimens containing doxorubicin ("A Predictive Model for Aggressive Non-Hodgkin's Lymphoma," 1993). Analysis of 1274 patients younger than 60 years showed three clinical features independently associated with survival: serum LDL (lactate dehydrogenase) levels, tumor stage, and their performance status ("A Predictive Model for Aggressive Non-Hodgkin's Lymphoma," 1993). Past studies showed the importance of gallium-67 uptake in lymphomas as a useful prognostic indicator (Janicek, et al., 1997). The importance of prognostic index is that good-risk patients can be identified for standard therapy and poor-risk patients can be identified for new research protocols to improve the rate of therapy. With conventional therapy only $25 \%$ of patients who were gallium-positive midway through therapy had durable responses, while $70 \%$ of those who were gallium-negative remained free of disease (Janicek, et al., 1997). In patients with stage I or II disease, regional therapy leads to longterm control, with relapse rate of $44 \%-47 \%$ at 10 years and survival rates of $75 \%$ for patients younger than 60 years (Vaughan Hudson, et al., 1994). Stage III and IV patients can be treated by alkylating agents, combination chemotherapy regimens with 2-4 drugs, and high 
dose therapy with bone marrow transplant reinfusion(Freedman, et al., 1996, Govindan, et al., 2009).

\section{Conclusions}

Thorough examination of the oral cavity should be part of the physical examination for everybody, but especially in HIV-positive individuals and those who are at a high risk for acquiring HIV infection. Oral lesions can not only compromise the quality of life and increase morbidity in patients with HIV/AIDS, but can also serve as indicators for the presence of the disease and disease progression. It is also very important for health care providers and medical practitioners from different specialties to collaborate in providing the overall care for these immune-compromised patients.

\section{References}

"1993 Revised Classification System for Hiv Infection and Expanded Surveillance Case Definition for Aids among Adolescents and Adults." MMWR Recomm Rep 41, no. RR-17 (1992): 1-19.

Al-Bakkal, Ghasaq, Giuseppe Ficarra, Karol McNeill, Lewis R. Eversole, Gaetana Sterrantino, and Catalena Birek. "Human Papilloma Virus Type 16 E6 Gene Expression in Oral Exophytic Epithelial Lesions as Detected by in Situ Rtpcr." Oral surgery, oral medicine, oral pathology, oral radiology, and endodontics 87, no. 2 (1999): 197-208.

Albrecht, J. C., J. Nicholas, D. Biller, K. R. Cameron, B. Biesinger, C. Newman, S. Wittmann, M. A. Craxton, H. Coleman, and B. Fleckenstein. "Primary Structure of the Herpesvirus Saimiri Genome." J. Virol. 66, no. 8 (1992): 5047-58.

Armitage, G. C. "Development of a Classification System for Periodontal Diseases and Conditions." Ann Periodontol 4, no. 1 (1999): 1-6.

Banin, S., L. Moyal, S. Y. Shieh, Y. Taya, C. W. Anderson, L. Chessa, N. I. Smorodinsky, C. Prives, Y. Reiss, Y. Shiloh, and Y. Ziv. "Enhanced Phosphorylation of P53 by Atm in Response to DNA Damage." Science 281, no. 5383 (1998): 1674-77.

Barnes, G. P., W. F. Bowles, 3rd, and H. G. Carter. "Acute Necrotizing Ulcerative Gingivitis: A Survey of 218 Cases." J Periodontol 44, no. 1 (1973): 35-42.

Barnes, Leon, Eugene N. Myers, and Emanuel P. Prokopakis. "Primary Malignant Lymphoma of the Parotid Gland." Arch Otolaryngol Head Neck Surg 124, no. 5 (1998): 573-77.

Bensadoun, Rene-Jean, Jamel Daoud, Brahim El Gueddari, Laurent Bastit, Rene Gourmet, Andrzej Rosikon, Christophe Allavena, Philippe Céruse, Gilles Calais, and Pierre Attali. "Comparison of the Efficacy and Safety of Miconazole 50-Mg Mucoadhesive Buccal Tablets with Miconazole 500-Mg Gel in the Treatment of Oropharyngeal Candidiasis." Cancer 112, no. 1 (2008): 204-11.

Bravo, I. M., M. Correnti, L. Escalona, M. Perrone, A. Brito, V. Tovar, and H. Rivera. "Prevalence of Oral Lesions in Hiv Patients Related to Cd4 Cell Count and Viral Load in a Venezuelan Population." Med Oral Patol Oral Cir Bucal 11, no. 1 (2006): E33-9. 
Calderone, R. A., and P. C. Braun. "Adherence and Receptor Relationships of Candida Albicans." Microbiol. Mol. Biol. Rev. 55, no. 1 (1991): 1-20.

Calderone, Richard A., and William A. Fonzi. "Virulence Factors of Candida Albicans." Trends in Microbiology 9, no. 7 (2001): 327-35.

Cattelan, A. M., M. L. Calabro, S. M. L. Aversa, M. Zanchetta, F. Meneghetti, A. De Rossi, and L. Chieco-Bianchi. "Regression of Aids-Related Kaposi's Sarcoma Following Antiretroviral Therapy with Protease Inhibitors: Biological Correlates of Clinical Outcome." European Journal of Cancer 35, no. 13 (1999): 1809-15.

Chaffin, W. Lajean, Jose Luis Lopez-Ribot, Manuel Casanova, Daniel Gozalbo, and Jose P. Martinez. "Cell Wall and Secreted Proteins of Candida Albicans: Identification, Function, and Expression." Microbiol. Mol. Biol. Rev. 62, no. 1 (1998): 130-80.

Charlier, C., E. Hart, A. Lefort, P. Ribaud, F. Dromer, D. W. Denning, and O. Lortholary. "Fluconazole for the Management of Invasive Candidiasis: Where Do We Stand after 15 Years?" Journal of Antimicrobial Chemotherapy 57, no. 3 (2006): 384-410.

Chi, Bo, Mingshan Qi, and Howard K. Kuramitsu. "Role of Dentilisin in Treponema Denticola Epithelial Cell Layer Penetration." Research in Microbiology 154, no. 9 (2003): 637-43.

"Classification and Diagnostic Criteria for Oral Lesions in Hiv Infection. Ec-Clearinghouse on Oral Problems Related to Hiv Infection and Who Collaborating Centre on Oral Manifestations of the Immunodeficiency Virus." J Oral Pathol Med 22, no. 7 (1993): 289-91.

Cogen, R. B., A. W. Stevens, Jr., S. Cohen-Cole, K. Kirk, and A. Freeman. "Leukocyte Function in the Etiology of Acute Necrotizing Ulcerative Gingivitis." J Periodontol 54, no. 7 (1983): 402-7.

Coogan, M. M., J. Greenspan, and S. J. Challacombe. "Oral Lesions in Infection with Human Immunodeficiency Virus." Bull World Health Organ 83, no. 9 (2005): 700-6.

D'Souza, Gypsyamber, Hao H. Zhang, Warren D. D'Souza, Robert R. Meyer, and Maura L. Gillison. "Moderate Predictive Value of Demographic and Behavioral Characteristics for a Diagnosis of Hpv16-Positive and Hpv16-Negative Head and Neck Cancer." Oral Oncology 46, no. 2: 100-04.

Davies, Andrew N., Susan R. Brailsford, and David Beighton. "Oral Candidosis in Patients with Advanced Cancer." Oral Oncology 42, no. 7 (2006): 698-702.

De Wit, Ronald, CharlesA B. Boucher, KeesH N. Veenhof, JanK M. E. Schattenkerk, PietJ M. Bakker, and SvenA Danner. "Clinical and Virological Effects of High-Dose Recombinant Interferon-? In Disseminated Aids-Related Kaposi's Sarcoma." The Lancet 332, no. 8622 (1988): 1214-17.

Economopoulos, Theofanis, Niki Asprou, Nicholas Stathakis, Efstathios Papageorgiou, John Dervenoulas, Katiana Xanthaki, and Sotos Raptis. "Primary Extranodal NonHodgkin's Lymphoma in Adults: Clinicopathological and Survival Characteristics." Leukemia \& Lymphoma 21, no. 1-2 (1996): 131-36.

Ellen, Richard P., and Vaia B. Galimanas. "Spirochetes at the Forefront of Periodontal Infections." Periodontology 2000 38, no. 1 (2005): 13-32. 
Eltom, Mohamed A., Ahmedin Jemal, Sam M. Mbulaiteye, Susan S. Devesa, and Robert J. Biggar. "Trends in Kaposi's Sarcoma and Non-Hodgkin's Lymphoma Incidence in the United States from 1973 through 1998." Journal of the National Cancer Institute 94, no. 16 (2002): 1204-10.

Eng, W., and C. J. Cockerell. "Histological Features of Kaposi Sarcoma in a Patient Receiving Highly Active Antiviral Therapy." Am J Dermatopathol 26, no. 2 (2004): 127-32.

Engels, E. A., R. M. Pfeiffer, J. J. Goedert, P. Virgo, T. S. McNeel, S. M. Scoppa, and R. J. Biggar. "Trends in Cancer Risk among People with Aids in the United States 19802002." AIDS 20, no. 12 (2006): 1645-54.

Falkler, W. A., Jr., S. A. Martin, J. W. Vincent, B. D. Tall, R. K. Nauman, and J. B. Suzuki. "A Clinical, Demographic and Microbiologic Study of Anug Patients in an Urban Dental School." J Clin Periodontol 14, no. 6 (1987): 307-14.

Fejerskov, O., B. Roed-Petersen, and J. J. Pindborg. "Clinical, Histological and Ultrastructural Features of a Possibly Virus-Induced Oral Leukoplakia." Acta Pathol Microbiol Scand A 85, no. 6 (1977): 897-906.

Fenno, J. Christopher, and Barry C. McBride. "Virulence Factors of Oral Treponemes." Anaerobe 4, no. 1 (1998): 1-17.

Filipovich, A. H., A. Mathur, D. Kamat, and R. S. Shapiro. "Primary Immunodeficiencies: Genetic Risk Factors for Lymphoma." Cancer Research 52, no. 19 Supplement (1992): 5465s-67s.

Freedman, A. S., J. G. Gribben, D. Neuberg, P. Mauch, R. J. Soiffer, K. C. Anderson, L. Pandite, M. J. Robertson, M. Kroon, J. Ritz, and L. M. Nadler. "High-Dose Therapy and Autologous Bone Marrow Transplantation in Patients with Follicular Lymphoma During First Remission." Blood 88, no. 7 (1996): 2780-86.

Fukuda, Y., T. Ishida, M. Fujimoto, T. Ueda, and K. Aozasa. "Malignant Lymphoma of the Oral Cavity: Clinicopathologic Analysis of 20 Cases." J Oral Pathol 16, no. 1 (1987): 8-12.

Gemmell, E., and G. J. Seymour. "Cytokine Profiles of Cells Extracted from Humans with Periodontal Diseases." Journal of Dental Research 77, no. 1 (1998): 16-26.

Gilbert, P. A., N. T. Brewer, and P. L. Reiter. "Association of Human Papillomavirus-Related Knowledge, Attitudes, and Beliefs with Hiv Status: A National Study of Gay Men." J Low Genit Tract Dis 15, no. 2: 83-8.

Gillison, Maura L., Gypsyamber D'Souza, William Westra, Elizabeth Sugar, Weihong Xiao, Shahnaz Begum, and Raphael Viscidi. "Distinct Risk Factor Profiles for Human Papillomavirus Type 16â€ $€^{\prime \prime}$ Positive and Human Papillomavirus Type 16â€ $\epsilon^{\prime \prime}$ Negative Head and Neck Cancers." Journal of the National Cancer Institute 100, no. 6 (2008): 407-20.

Glick, M., B. C. Muzyka, L. M. Salkin, and D. Lurie. "Necrotizing Ulcerative Periodontitis: A Marker for Immune Deterioration and a Predictor for the Diagnosis of Aids." $J$ Periodontol 65, no. 5 (1994): 393-7.

Goedert, J. J. "The Epidemiology of Acquired Immunodeficiency Syndrome Malignancies." Semin Oncol 27, no. 4 (2000): 390-401.

Goedert, J. J., M. G. Sarngadharan, R. J. Biggar, S. H. Weiss, D. M. Winn, R. J. Grossman, M. H. Greene, A. J. Bodner, D. L. Mann, D. M. Strong, and et al. "Determinants of 
Retrovirus (Htlv-Iii) Antibody and Immunodeficiency Conditions in Homosexual Men." Lancet 2, no. 8405 (1984): 711-6.

Goldman, H. M., and J. Bloom. "Topical Application of Aureomycin for the Treatment of the Acute Phase of Ulcerative Necrotizing Gingivitis (Vincent's Infection)." Oral Surg Oral Med Oral Pathol 3, no. 9 (1950): 1148-50.

Gottlieb, Michael S., Robert Schroff, Howard M. Schanker, Joel D. Weisman, Peng Thim Fan, Robert A. Wolf, and Andrew Saxon. "Pneumocystis Carinii Pneumonia and Mucosal Candidiasis in Previously Healthy Homosexual Men." New England Journal of Medicine 305, no. 24 (1981): 1425-31.

Govindan, Ramaswamy, Inc Ovid Technologies, Books@Ovid, and Collection Electronic Books. Devita, Hellman, and Rosenberg's Cancer Principles \& Practice of Oncology Review Lippincott William \& Wilkins, 2009 [cited.

Gowdey, G., R. K. Lee, and W. M. Carpenter. "Treatment of Hiv-Related Hairy Leukoplakia with Podophyllum Resin 25\% Solution." Oral Surg Oral Med Oral Pathol Oral Radiol Endod 79, no. 1 (1995): 64-7.

Greenspan, D., and J. S. Greenspan. "Oral Lesions of Hiv Infections: Features and Therapy." AIDS Clin Rev (1990): 81-93.

Hann, I. M., R. Corringham, M. Keaney, P. Noone, J. Fox, M. Szawatkowski, H. G. Prentice, H. A. Blacklock, M. Shannon, E. Gascoigne, E. Boesen, and A. V. Hoffbrand. "Ketoconazole Versus Nystatin Plus Amphotericin B for Fungal Prophylaxis in Severely Immunocompromised Patients." The Lancet 319, no. 8276 (1982): 826-29.

Hoefnagel, J. J., M. H. Vermeer, P. M. Jansen, G. J. Fleuren, C. J. L. M. Meijer, and R. Willemze. "Bcl-2, Bcl-6 and Cd10 Expression in Cutaneous B-Cell Lymphoma: Further Support for a Follicle Centre Cell Origin and Differential Diagnostic Significance." British Journal of Dermatology 149, no. 6 (2003): 1183-91.

Horning, G. M., and M. E. Cohen. "Necrotizing Ulcerative Gingivitis, Periodontitis, and Stomatitis: Clinical Staging and Predisposing Factors." J Periodontol 66, no. 11 (1995): 990-8.

Hostetter, M. K. "Adhesins and Ligands Involved in the Interaction of Candida Spp. With Epithelial and Endothelial Surfaces." Clin. Microbiol. Rev. 7, no. 1 (1994): 29-42.

"Human Papillomaviruses." IARC Monogr Eval Carcinog Risks Hum 90 (2007): 1-636.

Janicek, M., W. Kaplan, D. Neuberg, G. P. Canellos, L. N. Shulman, and M. A. Shipp. "Early Restaging Gallium Scans Predict Outcome in Poor-Prognosis Patients with Aggressive Non-Hodgkin's Lymphoma Treated with High-Dose Chop Chemotherapy." Journal of Clinical Oncology 15, no. 4 (1997): 1631-37.

Johnson, B. D., and D. Engel. "Acute Necrotizing Ulcerative Gingivitis. A Review of Diagnosis, Etiology and Treatment." J Periodontol 57, no. 3 (1986): 141-50.

Kramer, M. H. H., J. Hermans, E. Wijburg, K. Philippo, E. Geelen, J. H. J. M. van Krieken, D. de Jong, E. Maartense, E. Schuuring, and P. M. Kluin. "Clinical Relevance of Bcl2, Bcl6, and Myc Rearrangements in Diffuse Large B-Cell Lymphoma." Blood 92, no. 9 (1998): 3152-62. 
Kramer, M. H., S. Raghoebier, G. C. Beverstock, D. de Jong, P. M. Kluin, and J. C. KluinNelemans. "De Novo Acute B-Cell Leukemia with Translocation T(14;18): An Entity with a Poor Prognosis." Leukemia 5, no. 6 (1991): 473-8.

Kreimer, Aimee R., Gary M. Clifford, Peter Boyle, and Silvia Franceschi. "Human Papillomavirus Types in Head and Neck Squamous Cell Carcinomas Worldwide: A Systematic Review." Cancer Epidemiology Biomarkers E Prevention 14, no. 2 (2005): 467-75.

Lill, Claudia, Gabriela Kornek, Barbara Bachtiary, Edgar Selzer, Christian Schopper, Martina Mittlboeck, Martin Burian, Friedrich Wrba, and Dietmar Thurnher. "Survival of Patients with Hpv-Positive Oropharyngeal Cancer after Radiochemotherapy Is Significantly Enhanced." Wiener Klinische Wochenschrift.

Loesche, W. J., S. A. Syed, B. E. Laughon, and J. Stoll. "The Bacteriology of Acute Necrotizing Ulcerative Gingivitis." J Periodontol 53, no. 4 (1982): 223-30.

Loning, Thomas, Hans Ikenberg, Jurgen Becker, Lutz Gissmann, Ilsetraut Hoepfer, and Harald zur Hausen. "Analysis of Oral Papillomas, Leukoplakias, and Invasive Carcinomas for Human Papillomavirus Type Related DNA." J Investig Dermatol 84, no. 5 (1985): 417-20.

MacCarthy, D., and N. Claffey. "Acute Necrotizing Ulcerative Gingivitis Is Associated with Attachment Loss." J Clin Periodontol 18, no. 10 (1991): 776-9.

Montis. "[Treatment of Vincent's Angina with Penicillin]." Medicina (Madr) 18, no. 5 (1950): 376-8.

Moody, Cary A., Amelie Fradet-Turcotte, Jacques Archambault, and Laimonis A. Laimins. "Human Papillomaviruses Activate Caspases Upon Epithelial Differentiation to Induce Viral Genome Amplification." Proceedings of the National Academy of Sciences 104, no. 49 (2007): 19541-46.

Moody, Cary A., and Laimonis A. Laimins. "Human Papillomaviruses Activate the Atm DNA Damage Pathway for Viral Genome Amplification Upon Differentiation." PLoS Pathog 5, no. 10 (2009): e1000605.

Moore, Patrick S., and Yuan Chang. "Molecular Virology of Kaposi's Sarcoma "Associated Herpesvirus." Philosophical Transactions of the Royal Society of London. Series B: Biological Sciences 356, no. 1408 (2001): 499-516.

Nairy, Harish, Charyulu Narayana, Veena Shetty, and Prabhu Prabhakara. "A PseudoRandomised Clinical Trial of in Situ Gels of Fluconazole for the Treatment of Oropharngeal Candidiasis." Trials 12, no. 1: 99.

Nixon, C. S., M. J. Steffen, and J. L. Ebersole. "Cytokine Responses to Treponema Pectinovorum and Treponema Denticola in Human Gingival Fibroblasts." Infect Immun 68, no. 9 (2000): 5284-92.

Ollert, M. W., E. Wadsworth, and R. A. Calderone. "Reduced Expression of the Functionally Active Complement Receptor for Ic3b but Not for C3d on an Avirulent Mutant of Candida Albicans." Infect. Immun. 58, no. 4 (1990): 909-13.

Osoba, David, Donald W. Northfelt, David W. Budd, and David Himmelberger. "Effect of Treatment on Health-Related Quality of Life in Acquired Immunodeficiency Syndrome (Aids)-Related Kaposi's Sarcoma: A Randomized Trial of Pegylated- 
Liposomal Doxorubicin Versus Doxorubicin, Bleomycin, and Vincristine." Cancer Investigation 19, no. 6 (2001): 573-80.

Owens, Norma J., Charles H. Nightingale, Robert T. Schweizer, Peter K. Schauer, Paul T. Dekker, and Richard Quintiliani. "Prophylaxis of Oral Candidiasis with Clotrimazole Troches." Arch Intern Med 144, no. 2 (1984): 290-93.

Palmblad, J., B. LÖNnqvist, B. Carlsson, G. Grimfors, M. JÄRnmark, R. Lerner, P. Ljungman, C. NystrÖM-Rosander, B. Petrini, and G. ÖBerg. "Oral Ketoconazole Prophylaxis for Candida Infections During Induction Therapy for Acute Leukaemia in Adults: More Bacteraemias." Journal of Internal Medicine 231, no. 4 (1992): 363-70.

Palmer, G. D., P. G. Robinson, S. J. Challacombe, W. Birnbaum, D. Croser, P. L. Erridge, T. Hodgson, D. Lewis, A. McLaren, and J. M. Zakrzewska. "Aetiological Factors for Oral Manifestations of Hiv." Oral Dis 2, no. 3 (1996): 193-7.

Pantanowitz, L., and B. J. Dezube. "Kaposi Sarcoma of the Larynx." AIDS Read 16, no. 4 (2006): 194-5.

Pati, Shibani, Colleen B. Pelser, Joseph Dufraine, Joseph L. Bryant, Marvin S. Reitz, and Frank F. Weichold. "Antitumorigenic Effects of Hiv Protease Inhibitor Ritonavir: Inhibition of Kaposi Sarcoma." Blood 99, no. 10 (2002): 3771-79.

Patton, L. L., J. A. Phelan, F. J. Ramos-Gomez, W. Nittayananta, C. H. Shiboski, and T. L. Mbuguye. "Prevalence and Classification of Hiv-Associated Oral Lesions." Oral Dis 8 Suppl 2 (2002): 98-109.

Peruzzo, Daiane C., Bruno B. Benatti, Glaucia M. B. Ambrosano, Get $\tilde{A}^{\circ}$ lio R. Nogueira-Filho, Enilson A. Sallum, MÃ rcio Z. Casati, and Francisco H. Nociti. "A Systematic Review of Stress and Psychological Factors as Possible Risk Factors for Periodontal Disease." Journal of Periodontology 78, no. 8 (2007): 1491-504.

Philpott-Howard, J. N., J. J. Wade, G. J. Mufti, K. W. Brammer, G. Ehniniger, and Group Multicentre Study. "Randomized Comparison of Oral Fluconazole Versus Oral Polyenes for the Prevention of Fungal Infection in Patients at Risk of Neutropenia." Journal of Antimicrobial Chemotherapy 31, no. 6 (1993): 973-84.

Phiri, R., L. Feller, and E. Blignaut. "The Severity, Extent and Recurrence of Necrotizing Periodontal Disease in Relation to Hiv Status and Cd4+ T Cell Count." J Int Acad Periodontol 12, no. 4: 98-103.

"A Predictive Model for Aggressive Non-Hodgkin's Lymphoma." New England Journal of Medicine 329, no. 14 (1993): 987-94.

Resnick, L., J. S. Herbst, D. V. Ablashi, S. Atherton, B. Frank, L. Rosen, and S. N. Horwitz. "Regression of Oral Hairy Leukoplakia after Orally Administered Acyclovir Therapy." JAMA 259, no. 3 (1988): 384-8.

Rosenquist, K. "Risk Factors in Oral and Oropharyngeal Squamous Cell Carcinoma: A Population-Based Case-Control Study in Southern Sweden." Swed Dent J Suppl, no. 179 (2005): 1-66.

Rozenberg-Arska, M., A. W. Dekker, J. Branger, and J. Verhoef. "A Randomized Study to Compare Oral Fluconazole to Amphotericin B in the Prevention of Fungal Infections in Patients with Acute Leukaemia." Journal of Antimicrobial Chemotherapy 27, no. 3 (1991): 369-76. 
Rupniewska, Z. M. "[Role of the Ann Arbor Classification in the Staging of Non-Hodgkin's Lymphomas]." Pol Arch Med Wewn 61, no. 4 (1979): 317-21.

Sakai, H., T. Yasugi, J. D. Benson, J. J. Dowhanick, and P. M. Howley. "Targeted Mutagenesis of the Human Papillomavirus Type 16 E2 Transactivation Domain Reveals Separable Transcriptional Activation and DNA Replication Functions." J. Virol. 70, no. 3 (1996): 1602-11.

Samaranayake, L. P., P. L. Fidel, J. R. Naglik, S. P. Sweet, R. Teanpaisan, M. M. Coogan, E. Blignaut, and P. Wanzala. "Fungal Infections Associated with Hiv Infection." Oral Dis 8 Suppl 2 (2002): 151-60.

Schluger, S. "Necrotizing Ulcerative Gingivitis in the Army; Incidence, Communicability and Treatment." J Am Dent Assoc 38, no. 2 (1949): 174-83.

Schmidt-Westhausen, A., R. A. Schiller, H. D. Pohle, and P. A. Reichart. "Oral Candida and Enterobacteriaceae in Hiv-1 Infection: Correlation with Clinical Candidiasis and Antimycotic Therapy." J Oral Pathol Med 20, no. 10 (1991): 467-72.

Schofer, H., F. R. Ochsendorf, E. B. Helm, and R. Milbradt. "Treatment of Oral 'Hairy' Leukoplakia in Aids Patients with Vitamin a Acid (Topically) or Acyclovir (Systemically)." Dermatologica 174, no. 3 (1987): 150-1.

Scully, C., G. Laskaris, J. Pindborg, S. R. Porter, and P. Reichart. "Oral Manifestations of Hiv Infection and Their Management. I. More Common Lesions." Oral Surg Oral Med Oral Pathol 71, no. 2 (1991): 158-66.

Sgadari, Cecilia, Giovanni Barillari, Elena Toschi, Davide Carlei, Ilaria Bacigalupo, Sara Baccarini, Clelia Palladino, Patrizia Leone, Roberto Bugarini, Laura Malavasi, Aurelio Cafaro, Mario Falchi, Donatella Valdembri, Giovanni Rezza, Federico Bussolino, Paolo Monini, and Barbara Ensoli. "Hiv Protease Inhibitors Are Potent Anti-Angiogenic Molecules and Promote Regression of Kaposi Sarcoma." Nat Med 8, no. 3 (2002): 225-32.

Shangase, L., L. Feller, and E. Blignaut. "Necrotising Ulcerative Gingivitis/Periodontitis as Indicators of Hiv-Infection." SADJ 59, no. 3 (2004): 105-8.

Shiels, M. S., S. R. Cole, S. Wegner, H. Armenian, J. S. Chmiel, A. Ganesan, V. C. Marconi, O. Martinez-Maza, J. Martinson, A. Weintrob, L. P. Jacobson, and N. F. CrumCianflone. "Effect of Haart on Incident Cancer and Noncancer Aids Events among Male Hiv Seroconverters." J Acquir Immune Defic Syndr 48, no. 4 (2008): 485-90.

Shiels, Meredith S., Ruth M. Pfeiffer, H. Irene Hall, Jianmin Li, James J. Goedert, Lindsay M. Morton, Patricia Hartge, and Eric A. Engels. "Proportions of Kaposi Sarcoma, Selected Non-Hodgkin Lymphomas, and Cervical Cancer in the United States Occurring in Persons with Aids, 1980-2007." JAMA: The Journal of the American Medical Association 305, no. 14 (2011): 1450-59.

Shroyer, K. R., G. S. Lovelace, M. L. Abarca, R. H. Fennell, M. E. Corkill, W. D. Woodard, and G. H. Davilla. "Detection of Human Papillomavirus DNA by in Situ Hybridization and Polymerase Chain Reaction in Human Papillomavirus Equivocal and Dysplastic Cervical Biopsies." Hum Pathol 24, no. 9 (1993): 10126. 
Skobe, M., L. F. Brown, K. Tognazzi, R. K. Ganju, B. J. Dezube, K. Alitalo, and M. Detmar. "Vascular Endothelial Growth Factor-C (Vegf-C) and Its Receptors Kdr and Flt-4 Are Expressed in Aids-Associated Kaposi's Sarcoma." J Invest Dermatol 113, no. 6 (1999): 1047-53.

Sugiyama, Masaru, Ujjal Kumar Bhawal, Tamiko Dohmen, Shigehiro Ono, Miwa Miyauchi, and Takenori Ishikawa. "Detection of Human Papillomavirus-16 and Hpv-18 DNA in Normal, Dysplastic, and Malignant Oral Epithelium." Oral Surgery, Oral Medicine, Oral Pathology, Oral Radiology \& Endodontics 95, no. 5 (2003): 594-600.

Swift, Patrick S. "The Role of Radiation Therapy in the Management of Hiv-Related Kaposi's Sarcoma." Hematology/Oncology Clinics of North America 10, no. 5 (1996): 1069-80.

Taiwo, J. O. "Oral Hygiene Status and Necrotizing Ulcerative Gingivitis in Nigerian Children." J Periodontol 64, no. 11 (1993): 1071-4.

Tanabe, Shin-ichi, Charles Bodet, and Daniel Grenier. "Treponema Denticola Lipooligosaccharide Activates Gingival Fibroblasts and Upregulates Inflammatory Mediator Production." Journal of Cellular Physiology 216, no. 3 (2008): 727-31.

Tominaga, Kaoru, Hirobumi Morisaki, Yoko Kaneko, Atsushi Fujimoto, Takashi Tanaka, Motoaki Ohtsubo, Momoki Hirai, Hiroto Okayama, Kyoji Ikeda, and Makoto Nakanishi. "Role of Human Cds1 (Chk2) Kinase in DNA Damage Checkpoint and Its Regulation by P53." Journal of Biological Chemistry 274, no. 44 (1999): 31463-67.

Trattner, A., E. Hodak, M. David, and M. Sandbank. "The Appearance of Kaposi Sarcoma During Corticosteroid Therapy." Cancer 72, no. 5 (1993): 1779-83.

Tukutuku, K., L. Muyembe-Tamfum, K. Kayembe, W. Odio, K. Kandi, and M. Ntumba. "Oral Manifestations of Aids in a Heterosexual Population in a Zaire Hospital." J Oral Pathol Med 19, no. 5 (1990): 232-4.

Vaughan Hudson, B., G. Vaughan Hudson, K. A. MacLennan, L. Anderson, and D. C. Linch. "Clinical Stage 1 Non-Hodgkin's Lymphoma: Long-Term Follow-up of Patients Treated by the British National Lymphoma Investigation with Radiotherapy Alone as Initial Therapy." Br J Cancer 69, no. 6 (1994): 1088-93.

Vega, Francisco, Pei Lin, and L. Jeffrey Medeiros. "Extranodal Lymphomas of the Head and Neck." Annals of Diagnostic Pathology 9, no. 6 (2005): 340-50.

Vogler, W. R., L. G. Malcom, and E. F. Winton. "A Randomized Trial Comparing Ketoconazole and Nystatin Prophylactic Therapy in Neutropenic Patients." Cancer Invest 5, no. 4 (1987): 267-73.

Weninger, W., T. A. Partanen, S. Breiteneder-Geleff, C. Mayer, H. Kowalski, M. Mildner, J. Pammer, M. Sturzl, D. Kerjaschki, K. Alitalo, and E. Tschachler. "Expression of Vascular Endothelial Growth Factor Receptor-3 and Podoplanin Suggests a Lymphatic Endothelial Cell Origin of Kaposi's Sarcoma Tumor Cells." Lab Invest 79, no. 2 (1999): 243-51. 
Williams, C., J. M. Whitehouse, T. A. Lister, and P. F. Wrigley. "Oral Anticandidal Prophylaxis in Patients Undergoing Chemotherapy for Acut- Leukemia." Med Pediatr Oncol 3, no. 3 (1977): 275-80.

Worthington, H. V., J. E. Clarkson, and O. B. Eden. "Interventions for Preventing Oral Candidiasis for Patients with Cancer Receiving Treatment." Cochrane Database Syst Rev, no. 3 (2002): CD003807. 


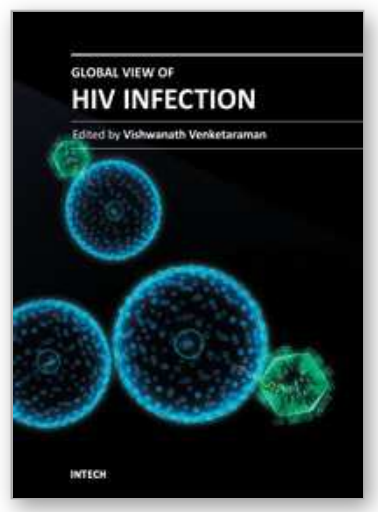

\author{
Global View of HIV Infection \\ Edited by Dr. Vishwanath Venketaraman
}

ISBN 978-953-307-671-3

Hard cover, 176 pages

Publisher InTech

Published online 26, October, 2011

Published in print edition October, 2011

Some of the topics covered in this book are: HIV infection HIV transmission Clinical symptoms of AIDS AIDS and opportunistic infection Prevention and treatment of HV Treatment of HIV infection and immune reconstitution

\title{
How to reference
}

In order to correctly reference this scholarly work, feel free to copy and paste the following:

Ranjitha Krishna, Saiprasad Zemse and Scott Derossi (2011). Individuals with HIV/AIDS: Clinical Manifestations in the Oral Cavity in the Post-HAART Era, Global View of HIV Infection, Dr. Vishwanath Venketaraman (Ed.), ISBN: 978-953-307-671-3, InTech, Available from:

http://www.intechopen.com/books/global-view-of-hiv-infection/individuals-with-hiv-aids-clinical-manifestationsin-the-oral-cavity-in-the-post-haart-era

\section{INTECH}

open science | open minds

\author{
InTech Europe \\ University Campus STeP Ri \\ Slavka Krautzeka 83/A \\ 51000 Rijeka, Croatia \\ Phone: +385 (51) 770447 \\ Fax: +385 (51) 686166 \\ www.intechopen.com
}

\author{
InTech China \\ Unit 405, Office Block, Hotel Equatorial Shanghai \\ No.65, Yan An Road (West), Shanghai, 200040, China \\ 中国上海市延安西路65号上海国际贵都大饭店办公楼405单元 \\ Phone: +86-21-62489820 \\ Fax: $+86-21-62489821$
}


(C) 2011 The Author(s). Licensee IntechOpen. This is an open access article distributed under the terms of the Creative Commons Attribution 3.0 License, which permits unrestricted use, distribution, and reproduction in any medium, provided the original work is properly cited. 